\title{
Nutritional Intake, White Matter Integrity, and Neurodevelopment in Extremely Preterm Born Infants
}

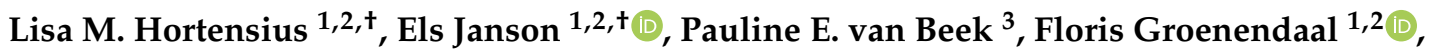 \\ Nathalie H. P. Claessens ${ }^{1,2}$, Henriette F. N. Swanenburg de Veye ${ }^{4}$, Maria J. C. Eijsermans ${ }^{1,5}$,

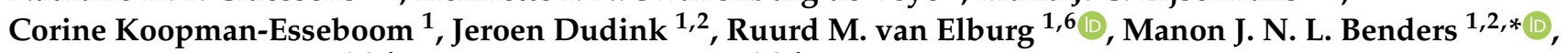 \\ Maria Luisa Tataranno ${ }^{1,2, \ddagger}$ and Niek E. van der Aa ${ }^{1,2, \ddagger}$
}

check for

updates

Citation: Hortensius, L.M.; Janson,

E.; van Beek, P.E.; Groenendaal, F.;

Claessens, N.H.P.; Swanenburg de

Veye, H.F.N.; Eijsermans, M.J.C.;

Koopman-Esseboom, C.; Dudink, J.;

van Elburg, R.M.; et al. Nutritional

Intake, White Matter Integrity, and

Neurodevelopment in Extremely

Preterm Born Infants. Nutrients 2021,

13, 3409. https://doi.org/10.3390/

nu13103409

Academic Editor: Stephane

V. Sizonenko

Received: 1 September 2021

Accepted: 22 September 2021

Published: 27 September 2021

Publisher's Note: MDPI stays neutral with regard to jurisdictional claims in published maps and institutional affiliations.

Copyright: (C) 2021 by the authors. Licensee MDPI, Basel, Switzerland. This article is an open access article distributed under the terms and conditions of the Creative Commons Attribution (CC BY) license (https:// creativecommons.org/licenses/by/ $4.0 /)$.
1 Department of Neonatology, Wilhelmina Children's Hospital, University Medical Center Utrecht, Utrecht University, 3584 EA Utrecht, The Netherlands; L.M.Hortensius-4@umcutrecht.nl (L.M.H.); E.Janson-6@umcutrecht.nl (E.J.); F.Groenendaal@umcutrecht.nl (F.G.);

N.H.P.Claessens-2@umcutrecht.nl (N.H.P.C.); M.J.C.Eijsermans@umcutrecht.nl (M.J.C.E.); C.Koopman@umcutrecht.nl (C.K.-E.); J.Dudink@umcutrecht.nl (J.D.); rm.vanelburg@amsterdamumc.nl (R.M.v.E.); M.L.Tataranno-2@umcutrecht.nl (M.L.T.); N.vanderAa@umcutrecht.nl (N.E.v.d.A.)

2 University Medical Center Utrecht Brain Center, Utrecht University, 3584 CG Utrecht, The Netherlands

3 Department of Neonatology, Máxima Medical Center, 5504 DB Veldhoven, The Netherlands; Pauline.van.Beek@mmc.nl

4 Department of Medical Psychology, Wilhelmina Children's Hospital, University Medical Center Utrecht, Utrecht University, 3584 EA Utrecht, The Netherlands; H.deVeye@umcutrecht.nl

5 Child Development and Exercise Center, Wilhelmina Children's Hospital, University Medical Center Utrecht, Utrecht University, 3584 EA Utrecht, The Netherlands

6 Emma Children's Hospital, Amsterdam University Medical Center, University of Amsterdam, 1105 AZ Amsterdam, The Netherlands

* Correspondence: m.benders@umcutrecht.nl

$\dagger$ These authors contributed equally to this work.

$\ddagger$ These authors contributed equally to this work.

Abstract: Background: Determining optimal nutritional regimens in extremely preterm infants remains challenging. This study aimed to evaluate the effect of a new nutritional regimen and individual macronutrient intake on white matter integrity and neurodevelopmental outcome. Methods: Two retrospective cohorts of extremely preterm infants (gestational age $<28$ weeks) were included. Cohort $\mathrm{B}(n=79)$ received a new nutritional regimen, with more rapidly increased, higher protein intake compared to cohort A $(n=99)$. Individual protein, lipid, and caloric intakes were calculated for the first 28 postnatal days. Diffusion tensor imaging was performed at term-equivalent age, and cognitive and motor development were evaluated at 2 years corrected age (CA) (Bayley-III-NL) and 5.9 years chronological age (WPPSI-III-NL, MABC-2-NL). Results: Compared to cohort A, infants in cohort B had significantly higher protein intake $(3.4 \mathrm{~g} / \mathrm{kg} /$ day vs. $2.7 \mathrm{~g} / \mathrm{kg} /$ day $)$ and higher fractional anisotropy (FA) in several white matter tracts but lower motor scores at 2 years CA (mean (SD) 103 (12) vs. 109 (12)). Higher protein intake was associated with higher FA and lower motor scores at 2 years $C A(B=-6.7, p=0.001)$. However, motor scores at 2 years $C A$ were still within the normal range and differences were not sustained at 5.9 years. There were no significant associations with lipid or caloric intake. Conclusion: In extremely preterm born infants, postnatal protein intake seems important for white matter development but does not necessarily improve long-term cognitive and motor development.

Keywords: nutrition; extremely preterm infant; diffusion tensor imaging; white matter; neurodevelopmental outcome 


\section{Introduction}

Adequate nutritional intake in extremely preterm (EP) infants (gestational age $(\mathrm{GA})<28$ weeks) is very important to achieve growth similar to fetal growth in utero. Postnatal growth is positively associated with different measures of brain development, including cortical maturation [1], linear measures of brain size [2], brain volumes [3], and neurodevelopmental outcome (NDO) [4-6]. Additionally, a recent systematic review showed that nutritional intake is independently associated with brain development [7]. Early cumulative fat and energy intakes were associated with larger brain volumes, improved white matter integrity [3,8], and lower brain injury scores [9]. Although a positive association between cumulative protein intake and total brain volume has been shown $[8,10]$, only enteral protein intake has previously been associated with improved white matter integrity $[3,8]$. The role of the macronutrient administration route (i.e., enteral or parenteral) has not yet been fully elucidated, but enteral nutrition is suggested to contribute most to brain development $[3,8]$.

Despite promising associations between nutrient intake and brain development, nutritional effects on NDO remain inconclusive [3,11-15]. A meta-analysis revealed that increased early enteral nutrition in preterm infants may support survival without neurodevelopmental impairment [16]. However, most included studies were based on outdated nutritional practices and/or reported only a short-term follow-up. Studies that assessed nutritional intake in EP infants in relation to brain development and/or NDO are often heterogeneous in methods and results, making it difficult to determine the optimal feeding regimen for this population [15,17].

Recently, we found that implementation of a new nutritional regimen with an increased protein intake $(3.4 \mathrm{~g} / \mathrm{kg} /$ day vs. $2.7 \mathrm{~g} / \mathrm{kg} /$ day $)$ was associated with globally increased brain volumes at 30 weeks postmenstrual age (PMA) but not at term equivalent age (TEA) [10]. In the current study, we further explored the effect of this new nutritional regimen on (a) white matter integrity at TEA and (b) NDO at 2 years CA and 5.9 years chronological age. Furthermore, we evaluated the effects of individual total, enteral, and parenteral macronutrient intakes (protein, lipids, and calories) during the first 28 postnatal days on (c) white matter integrity at TEA and (d) NDO at 2 years CA and 5.9 years chronological age. We hypothesized that the new nutritional protocol and increased macronutrient intake would be positively associated with white matter integrity and NDO.

\section{Materials and Methods}

\subsection{Patient Population}

For this retrospective study, infants from a previously derived retrospective study cohort were eligible for inclusion. The cohort consisted of 178 infants born $<28$ weeks GA, between January 2011 and December 2015, with nutritional parameters and segmentation of magnetic resonance imaging (MRI) at TEA available [10]. In the current study, infants were included in the white matter integrity analysis if a diffusion tensor imaging (DTI) scan at TEA of sufficient quality was available, and in the NDO analysis if neurodevelopmental assessment was performed at 2 years CA and/or 5.9 years chronological age. The medical ethics committee of the University Medical Center Utrecht approved the use of clinical and MRI data for anonymous data analysis and waived the requirement to obtain written informed consent. All data were obtained as part of the standard clinical protocol.

\subsection{Data Collection and Nutritional Regimens}

Clinical data were collected as described previously [10]. Severe brain injury was defined as grade 3 or 4 intraventricular hemorrhage according to Papile, post-hemorrhagic ventricular dilatation requiring drainage, cystic periventricular leukomalacia, and/or a cerebellar hemorrhage involving $>50 \%$ of one hemisphere. Severe illness was defined as $>7$ days mechanical ventilation and/or abdominal surgery. Body weight Z-scores were calculated using a national reference [18]. Maternal education was defined as low, middle, or high, according to Statistics Netherlands [19]. Enteral, parenteral, and total protein 
(g), lipid (g), and caloric (kcal) intakes per kilogram body weight and protein/energy ratio were calculated for the first 28 postnatal days. Macronutrient content from preterm formula was sourced from nutritional information printed on the nutrition product. Energy, protein, and fat concentrations in breast milk were assumed to be $68 \mathrm{kcal}, 1.0 \mathrm{~g}$ protein, and $4.0 \mathrm{~g}$ lipids, respectively, per $100 \mathrm{~mL}$. The nutritional regimens have been described previously [10]. In summary, up to September 2013, parenteral nutrition was introduced on the second postnatal day, and protein and lipid intake were slowly increased until postnatal day 5 to a maximum of $2.6 \mathrm{~g} / \mathrm{kg}$ protein and $1.7 \mathrm{~g} / \mathrm{kg}$ lipids (cohort A). In September 2013, the nutritional regimen was changed to meet a new national guideline [20]. Parenteral nutrition was started as soon as possible after admission with $1 \mathrm{~g} / \mathrm{kg}$ protein and lipid intake, and increased to a maximum of $3.5 \mathrm{~g} / \mathrm{kg}$ protein and $4 \mathrm{~g} / \mathrm{kg}$ lipids on postnatal day 3 (cohort B). In both cohorts, minimal enteral feeding was started shortly after birth and enteral intake was increased daily if tolerated, starting at $24-48 \mathrm{~h}$ after birth. The start and increase of enteral intake did not differ between cohort A and B.

\subsection{MRI Acquisition and Processing}

MRI was performed as previously described [10]. The DTI sequence changed in 2013, resulting in two different sequences used in this study. The previous DTI sequence used the following parameters: repetition time $=5800 \mathrm{~ms}$; echo time $=70 \mathrm{~ms}$; voxel size $=1.4 \times 1.4 \times 2.0$; number of slices $=50$; field of view $=18.0 \mathrm{~cm} ; \mathrm{b}$ value $=800 \mathrm{~s} / \mathrm{mm}^{2}$; number of diffusion weighted directions $=32$; number of non-diffusion weighted images $=1$. The current DTI sequence used the following parameters: repetition time $=6500 \mathrm{~ms}$; echo time $=80 \mathrm{~ms}$; voxel size $=2.0 \times 2.0 \times 2.0$; number of slices $=45$; field of view $=16.0 \mathrm{~cm} ; \mathrm{b}$ value $=800 \mathrm{~s} / \mathrm{mm}^{2}$; number of diffusion weighted directions $=45$; number of non-diffusion weighted images $=1$. The use of two DTI sequences was accounted for in the statistical analysis.

DTI data were analyzed in the source FMRIB Software Library [21]. After brain extraction and motion correction, individual FA maps were computed by fitting a tensor model to the raw diffusion data. Tract-based spatial statistics (TBSS) [22] was used to enable voxel-wise statistical analyses on the FA data. First, all individual FA maps were aligned to a representative target in common space, using the nonlinear registration tool FNIRT [23,24]. Second, a mean FA image was created and thinned to create a mean FA skeleton representing the centers of all tracts common to the group, thresholded at a FA $>0.2$. Third, all aligned individual FA images were projected onto this skeleton. The resulting data were used for voxel-wise statistics.

\subsection{Neurodevelopmental Outcome Measurements}

NDO was assessed at the outpatient clinic by developmental specialists (pediatric physiotherapist, child psychologist, and/or neonatologist). At 2 years CA, outcome included cognitive and (fine, gross, and total) motor development using the Bayley Scales of Infant and Toddler-Development, third edition, Dutch (Bayley-III-NL; normative mean (SD) for cognition and total motor score: 100 (15); fine and gross motor score: 10 (3)). At 5.9 years chronological age, outcome included cognition (full-scale IQ, verbal IQ, performance IQ, and processing speed), using the Wechsler Preschool and Primary Scale of Intelligence, third edition, Dutch (WPPSI-III-NL; normative mean (SD) 100 (15)) and motor development (total score, manual dexterity, aiming and catching, and balance) using the Movement Assessment Battery for Children, second edition, Dutch (M-ABC-II-NL; standard score mean (SD) 10 (3)). Higher scores indicate better functioning.

\subsection{Statistical Analysis}

\subsubsection{White Matter Integrity}

Associations between the nutritional regimen/individual macronutrient intake and white matter integrity were evaluated. Associations between enteral/parenteral intakes and white matter integrity were analyzed post-hoc, for exploratory purposes. DTI data were further analyzed using FSL's Randomise tool, which is a nonparametric cluster 
inference program using the standard general linear model [25]. Statistical inference was based on threshold-free cluster enhancement [26]. Additionally, 5000 permutations were performed to control for the family-wise error rate [27] and a threshold for statistical significance was set at $p<0.05$. The DTI sequence (old vs. new), PMA at time of MRI, GA at birth, birth weight Z-score, sex, severe brain injury, and severe illness were included as confounders.

\subsubsection{Neurodevelopmental Outcome}

All analyses with NDO data were performed using R version 3.5.2 [28]. Depending on the distribution of the data, Student's $t$-tests or Mann-Whitney-U tests (continuous data) and chi-square statistics or Fisher's Exact Test (categorical data) were performed to test for cohort differences. Cohort differences for all sub scores of the follow-up tests were analyzed post-hoc, for exploratory purposes. To further investigate the associations between nutritional regimen/daily macronutrient intake and NDO, multivariable analysis was performed, adjusting for GA at birth, birth weight Z-score, sex, severe brain injury, severe illness, and maternal education. Associations between enteral/parenteral intakes and NDO were analyzed post-hoc, for exploratory purposes. A $p$-value $<0.05$ was considered significant.

\section{Results}

\subsection{Patient Population}

In total, 178 children were eligible for inclusion: 99 in cohort A and 79 in cohort B [10]. Of the total cohort, 123 infants were included in the DTI analysis (69\%), and 161 (90\%) and $154(87 \%)$ children were included in follow-up analyses at 2 years CA and 5.9 years chronological age, respectively (Figure 1). Besides birth weight and birth weight Z-score, the clinical characteristics of infants with and without good-quality DTI did not differ (Supplementary Materials Table S1). Clinical characteristics did not differ between infants with and without follow-up at both ages (Supplementary Materials Table S1). Table 1 shows the baseline characteristics of the total cohort for children included in DTI and follow-up analyses at both ages. Baseline characteristics were similar in both nutritional cohorts (Supplementary Materials Table S2).

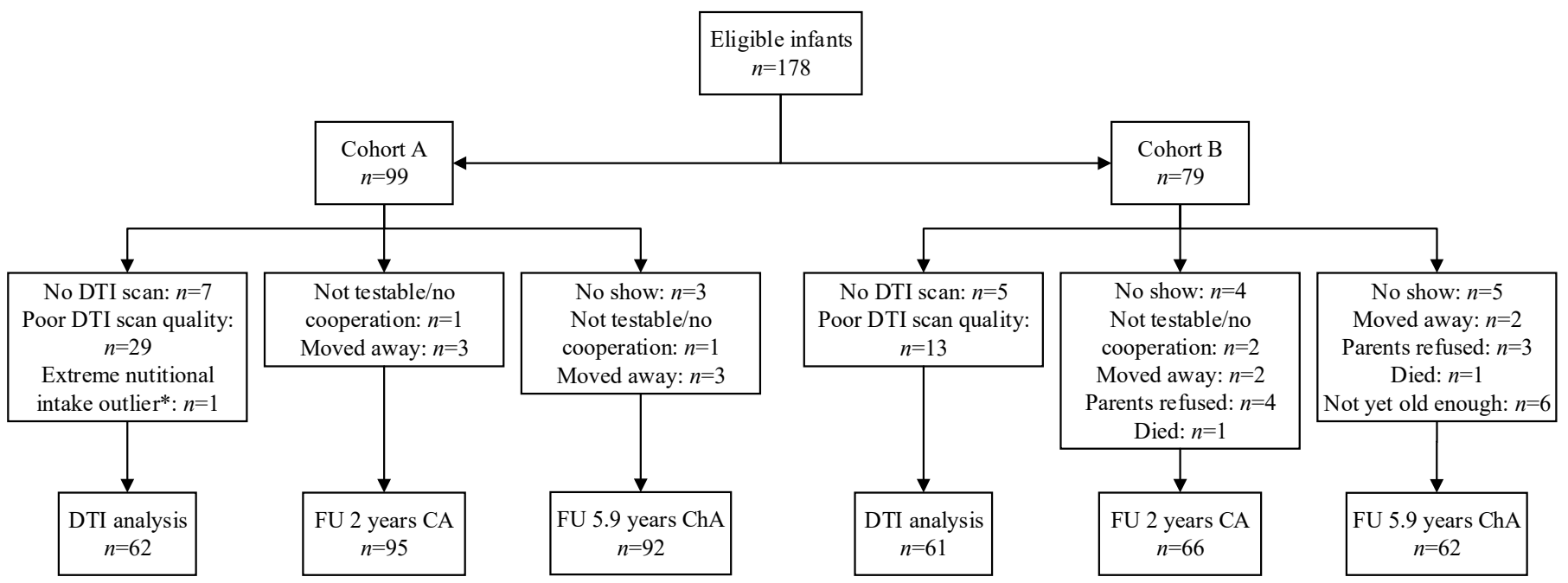

Figure 1. Flowchart of inclusion. DTI = diffusion tensor imaging; $\mathrm{FU}=$ follow-up; $\mathrm{CA}=$ corrected age; $\mathrm{ChA}=$ chronological age. ${ }^{*}>3$ standard deviations from the mean enteral and parenteral intake that caused significance. 
Table 1. Baseline characteristics of the included children.

\begin{tabular}{lccc}
\hline & $\begin{array}{c}\text { DTI Analysis } \\
(\boldsymbol{n = 1 2 3 )}\end{array}$ & $\begin{array}{c}\text { 2 Years Corrected Age } \\
(\boldsymbol{n}=\mathbf{1 6 1})\end{array}$ & $\begin{array}{c}\text { 5.9 Years Chronological Age } \\
(\boldsymbol{n}=\mathbf{1 5 4})\end{array}$ \\
\hline Male (\%) & $57(46)$ & $75(47)$ & $72(47)$ \\
Gestational age (weeks) (median (Q1; Q3)) & $26+3(25+6 ; 27+2)$ & $26+3(25+6 ; 27+1)$ & $26+3(25+6 ; 27+2)$ \\
Birth weight (g) (median (Q1; Q3)) & $880(784 ; 1000)$ & $870(750 ; 995)$ & $870(750 ; 1000)$ \\
Birth weight Z-score (mean (SD)) & $0.39(0.88)$ & $0.30(0.91)$ & $0.28(0.90)$ \\
SGA (<10th percentile) (\%) & $5(4)$ & $8(5)$ & $8(5)$ \\
Multiplicity (\%) & $36(29)$ & $52(32)$ & $52(34)$ \\
Apgar 5 min (median (Q1; Q3)) & $8(7 ; 8)$ & $8(7 ; 9)$ & $8(7 ; 9)$ \\
Days parental nutrition (median (Q1; Q3)) & $13(10 ; 17)$ & $12(10 ; 17)$ & $12(10 ; 17)$ \\
>7 days of ventilation (\%) & $62(50)$ & $83(52)$ & $79(51)$ \\
Abdominal surgery (\%) & $10(8)$ & $14(9)$ & $14(9)$ \\
Severe brain injury (\%) & $14(11)$ & $17(11)$ & $15(10)$ \\
Sepsis (\%) & $48(39)$ & $62(39)$ & $59(38)$ \\
\hline
\end{tabular}

DTI = diffusion tensor imaging; SGA = small for gestational age.

\subsection{Nutritional Details}

Nutritional details are shown in Table 2. Infants in cohort B had significantly higher total protein intake, higher caloric intake, and higher protein/energy ratio in the first 28 postnatal days compared to infants in cohort $\mathrm{A}$. Despite the change in nutritional regimen, lipid intake was similar in cohort A and B, because infants in cohort A received more lipids than should have been provided based on the nutritional regimen at the time. Infants in cohort $B$ received a relatively smaller amount of their proteins and lipids enterally compared to infants in cohort A.

Table 2. Nutritional details of infants in cohort A and B.

\begin{tabular}{|c|c|c|c|c|c|c|c|c|c|}
\hline & \multicolumn{3}{|c|}{ DTI Analysis } & \multicolumn{3}{|c|}{2 Years Corrected Age } & \multicolumn{3}{|c|}{ 5.9 Years Chronological Age } \\
\hline & $\begin{array}{c}\text { Cohort A } \\
(n=63)\end{array}$ & $\begin{array}{l}\text { Cohort B } \\
(n=60)\end{array}$ & $p$-Value & $\begin{array}{c}\text { Cohort A } \\
(n=95)\end{array}$ & $\begin{array}{c}\text { Cohort B } \\
(n=66)\end{array}$ & $p$-Value & $\begin{array}{c}\text { Cohort A } \\
(n=92)\end{array}$ & $\begin{array}{c}\text { Cohort B } \\
(n=62)\end{array}$ & $p$-Value \\
\hline \multicolumn{10}{|l|}{ Total } \\
\hline Protein $(\mathrm{g} / \mathrm{kg})$ & $\begin{array}{c}75 \\
(72 ; 82)\end{array}$ & $\begin{array}{c}97 \\
(93 ; 99)\end{array}$ & $<0.001^{\#}$ & $\begin{array}{c}74 \\
(71 ; 81)\end{array}$ & $\begin{array}{c}96 \\
(93 ; 99)\end{array}$ & $<0.001^{\#}$ & $\begin{array}{c}74 \\
(71 ; 80)\end{array}$ & $\begin{array}{c}97 \\
(94 ; 99)\end{array}$ & $<0.001^{\#}$ \\
\hline Lipids (g/kg) & $\begin{array}{c}135 \\
(121 ; 148)\end{array}$ & $\begin{array}{c}136 \\
(124 ; 144)\end{array}$ & 0.71 & $\begin{array}{c}137 \\
(120 ; 148)\end{array}$ & $\begin{array}{c}134 \\
(123 ; 144)\end{array}$ & 0.55 & $\begin{array}{c}136 \\
(119 ; 148)\end{array}$ & $\begin{array}{c}135 \\
(124 ; 144)\end{array}$ & 0.87 \\
\hline $\begin{array}{l}\text { Calories } \\
(\mathrm{kcal} / \mathrm{kg})\end{array}$ & $\begin{array}{c}2924 \\
(2710 ; 3157)\end{array}$ & $\begin{array}{c}3075 \\
(2895 ; 3181)\end{array}$ & $0.02 *$ & $\begin{array}{c}2924 \\
(2707 ; 3149)\end{array}$ & $\begin{array}{c}3038 \\
(2864 ; 3177)\end{array}$ & 0.07 & $\begin{array}{c}2924 \\
(2699 ; 3155)\end{array}$ & $\begin{array}{c}3055 \\
(2906 ; 3177)\end{array}$ & $0.03 *$ \\
\hline \multicolumn{10}{|l|}{ Daily } \\
\hline Protein $(\mathrm{g} / \mathrm{kg})$ & $\begin{array}{c}2.7 \\
(2.6 ; 2.9)\end{array}$ & $\begin{array}{c}3.5 \\
(3.3 ; 3.5)\end{array}$ & $<0.001^{\#}$ & $\begin{array}{c}2.7 \\
(2.5 ; 2.9)\end{array}$ & $\begin{array}{c}3.4 \\
(3.3 ; 3.5)\end{array}$ & $<0.001^{\#}$ & $\begin{array}{c}2.7 \\
(2.5 ; 2.8)\end{array}$ & $\begin{array}{c}3.5 \\
(3.3 ; 3.5)\end{array}$ & $<0.001$ \# \\
\hline Lipids (g/kg) & $\begin{array}{c}4.8 \\
(4.3 ; 5.3)\end{array}$ & $\begin{array}{c}4.9 \\
(4.4 ; 5.2)\end{array}$ & 0.71 & $\begin{array}{c}4.9 \\
(4.3 ; 5.3)\end{array}$ & $\begin{array}{c}4.8 \\
(4.4 ; 5.1)\end{array}$ & 0.55 & $\begin{array}{c}4.9 \\
(4.3 ; 5.3)\end{array}$ & $\begin{array}{c}4.8 \\
(4.4 ; 5.1)\end{array}$ & 0.87 \\
\hline $\begin{array}{l}\text { Calories } \\
(\mathrm{kcal} / \mathrm{kg})\end{array}$ & $\begin{array}{c}104 \\
(97 ; 113)\end{array}$ & $\begin{array}{c}110 \\
(103 ; 114)\end{array}$ & $0.02 *$ & $\begin{array}{c}104 \\
(97 ; 112)\end{array}$ & $\begin{array}{c}108 \\
(102 ; 113)\end{array}$ & 0.07 & $\begin{array}{c}104 \\
(96 ; 113)\end{array}$ & $\begin{array}{c}109 \\
(104 ; 113)\end{array}$ & $0.03 *$ \\
\hline \multicolumn{10}{|l|}{$\%$ enteral } \\
\hline Protein & $\begin{array}{c}72 \% \\
(61 \% ; 80 \%)\end{array}$ & $\begin{array}{c}70 \% \\
(59 \% ; 76 \%)\end{array}$ & 0.33 & $\begin{array}{c}73 \% \\
(60 \% ; 82 \%)\end{array}$ & $\begin{array}{c}69 \% \\
(59 \% ; 76 \%)\end{array}$ & $0.05 *$ & $\begin{array}{c}72 \% \\
(59 \% ; 82 \%)\end{array}$ & $\begin{array}{c}69 \% \\
(59 \% ; 76 \%)\end{array}$ & 0.12 \\
\hline Lipids & $\begin{array}{c}92 \% \\
(87 \% ; 95 \%)\end{array}$ & $\begin{array}{c}90 \% \\
(84 \% ; 93 \%)\end{array}$ & 0.06 & $\begin{array}{c}92 \% \\
(87 \% ; 95 \%)\end{array}$ & $\begin{array}{c}90 \% \\
(84 \% ; 93 \%)\end{array}$ & $0.01 *$ & $\begin{array}{c}92 \% \\
(87 \% ; 95 \%)\end{array}$ & $\begin{array}{c}90 \% \\
(85 \% ; 93 \%)\end{array}$ & $0.02 *$ \\
\hline Calories & $\begin{array}{c}83 \% \\
(75 \% ; 89 \%)\end{array}$ & $\begin{array}{c}83 \% \\
(72 \% ; 87 \%)\end{array}$ & 0.65 & $\begin{array}{c}84 \% \\
(74 \% ; 89 \%)\end{array}$ & $\begin{array}{c}82 \% \\
(73 \% ; 87 \%)\end{array}$ & 0.15 & $\begin{array}{c}83 \% \\
(74 \% ; 89 \%)\end{array}$ & $\begin{array}{c}82 \% \\
(74 \% ; 87 \%)\end{array}$ & 0.31 \\
\hline \multicolumn{10}{|c|}{ Protein/energy ratio } \\
\hline $\begin{array}{l}\text { Protein }(g) / 100 \\
\text { kcal }\end{array}$ & $\begin{array}{c}2.6 \\
(2.4 ; 2.9)\end{array}$ & $\begin{array}{c}3.2 \\
(3.1 ; 3.3)\end{array}$ & $<0.001 *$ & $\begin{array}{c}2.6 \\
(2.4 ; 2.9)\end{array}$ & $\begin{array}{c}3.2 \\
(3.1 ; 3.3)\end{array}$ & $<0.001 *$ & $\begin{array}{c}2.6 \\
(2.4 ; 2.9)\end{array}$ & $\begin{array}{c}3.2 \\
(3.1 ; 3.3)\end{array}$ & $<0.001 *$ \\
\hline
\end{tabular}

Cumulative intake (parenteral + enteral) over first 28 postnatal days (Total), daily intake (Daily), the amount of intake received enteral (\% enteral), and the protein/energy ratio (Protein/energy ratio), compared between cohort A and B. Daily intake means average daily intake. Numbers are presented as median (Q1;Q3). DTI = diffusion tensor imaging; ${ }^{*} p<0.05$; ${ }^{*} p<0.001$. 


\subsection{Nutritional Intake and White Matter Integrity}

Infants in cohort B had significantly higher FA in voxels of several white matter tracts compared to infants in cohort A. These tracts include the body of the corpus callosum, superior and posterior corona radiata, superior longitudinal fasciculus, retrolenticular part of the internal capsule, left sagittal stratum and posterior thalamic radiation, and right posterior limb of the internal capsule and superior cerebral peduncle (Figure 2A). Total protein intake during the first 28 postnatal days was significantly positively associated with FA in similar white matter tracts (Figure 2B). Cumulative enteral protein intake $(\mathrm{g} / \mathrm{kg}$ ) was significantly positively associated with FA in the left posterior thalamic radiation (Supplementary Materials Figure S1), while cumulative parenteral protein intake $(\mathrm{g} / \mathrm{kg}$ ) was not significantly associated with FA. Total, enteral, and parenteral lipid and caloric intake were not significantly associated with FA (data not shown).

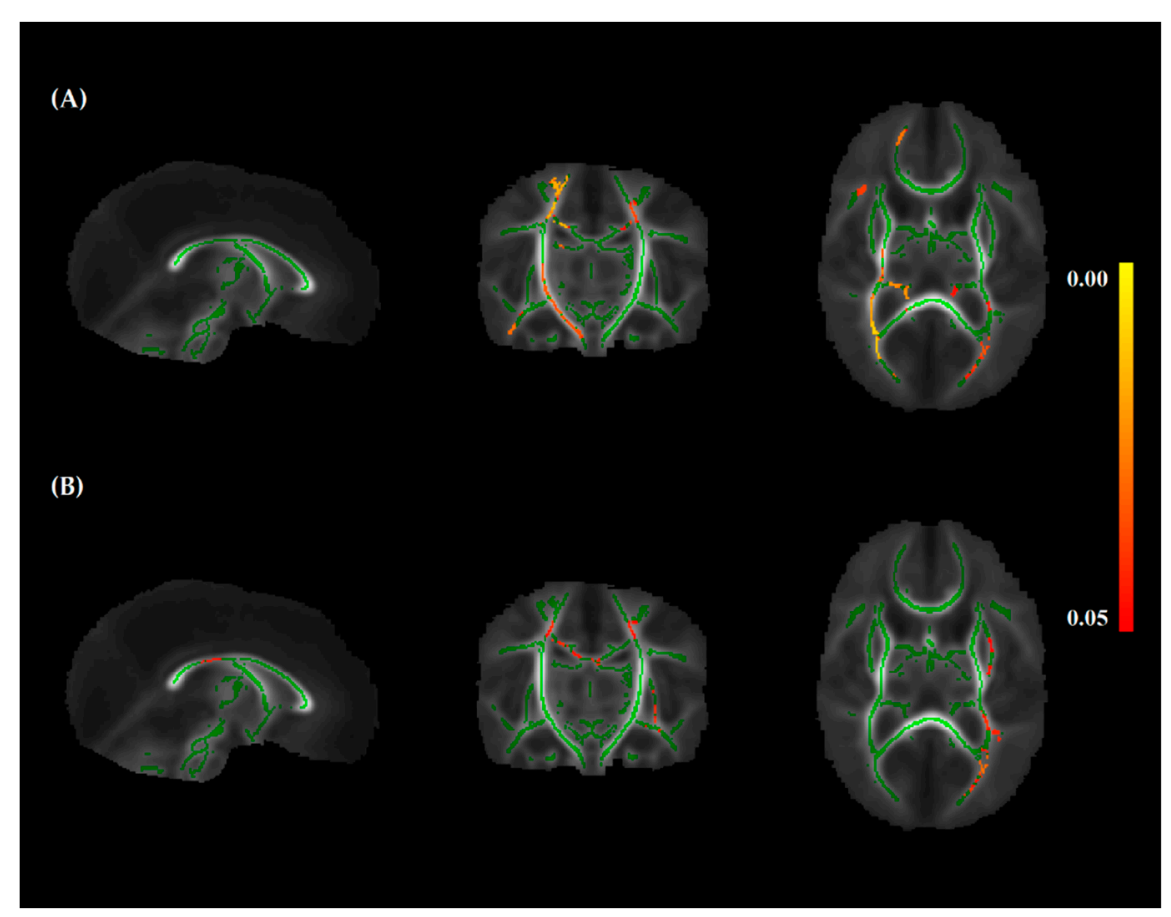

Figure 2. The introduction of the new nutrition protocol was associated with higher FA in several white matter tracts (A). Independent of the nutrition protocol, total protein intake was also associated with higher FA (B). Significant voxels (red-yellow; color bar indicates $p$-value) are presented on top of the mean FA skeleton (green) and are viewed from a sagittal (left), coronal (middle), and axial (right) perspective.

\subsection{Nutritional Intake and Neurodevelopmental Outcome at 2 Years CA and 5.9 Years Chronological Age}

Cognitive and motor outcome, including all exploratory analyzed sub scores of the follow-up tests, are shown in Table 3, and total scores are visualized in Figure 3. Total motor scores at 2 years CA were significantly lower in children in cohort B than cohort A (mean (SD) 103 (12) vs. 109 (12), respectively, $p=0.005$ ), although within normal range. The difference in the total motor score seems mainly driven by significantly lower fine motor scores in children in cohort B (mean (SD) 11 (2.6) vs. $13(2.2), p=0.002$ ). After adjustment for confounders, children in cohort $B$ still had significantly lower total motor scores at 2 years $C A(B=-5.2,95 \% C I-8.9$ to $-1.5, p=0.007)$ (Table 4$)$. Cognitive scores at 2 years $\mathrm{CA}$ and cognitive and motor scores at 5.9 years chronological age were similar in cohort $\mathrm{A}$ and $B$, and within the normal range. 
Table 3. Cognitive and motor outcome at both follow-up ages for cohort A and B.

\begin{tabular}{lccc}
\hline & Cohort A & Cohort B & $p$-Value \\
\hline 2 years corrected age & & & \\
\hline Cognition & $n=95$ & $n=66$ & 0.20 \\
Cognitive score & $101(16)$ & $104(16)$ & \\
Motor & $n=94$ & $n=61$ & $0.005^{* *}$ \\
Total motor score & $109(12)$ & $103(12)$ & $0.002^{* *}$ \\
Fine motor score & $13(2.2)$ & $11(2.6)$ & 0.12 \\
Gross motor score & $8.1(2.7)$ & $7.5(2.5)$ & \\
\hline 5.9 years chronological age & & & 0.99 \\
\hline Cognition & $n=80$ & $n=53$ & 0.88 \\
Full scale IQ & $94(15)$ & $94(16)$ & 0.72 \\
Verbal IQ & $98(18)$ & $97(14)$ & 0.46 \\
Performance IQ & $96(13)$ & $97(15)$ & 0.92 \\
Processing speed & $90(16)$ & $88(15)$ & 0.26 \\
Motor & $n=91$ & $n=60$ & 0.73 \\
Total motor score & $6.4(2.6)$ & $6.8(3.9)$ & 0.92 \\
Manual dexterity & $6.7(2.5)$ & $7.2(3.3)$ & $7.9(3.7)$ \\
Aiming and catching & $7.7(2.7)$ & $7.9(3.3)$ & \\
Balance & $7.9(2.9)$ & & \\
\hline
\end{tabular}

Scores are presented as mean (SD); IQ = intelligence quotient. ${ }^{* *} p<0.01$. Motor and cognitive scores 2 years corrected age: Bayley Scales of Infant and Toddler-Development. Cognitive score 5.9 years chronological age: Wechsler Preschool and Primary Scale of Intelligence. Motor score 5.9 years chronological age: Movement Assessment Battery for Children.

(A)

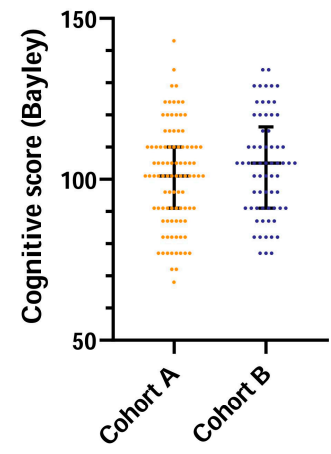

(C)

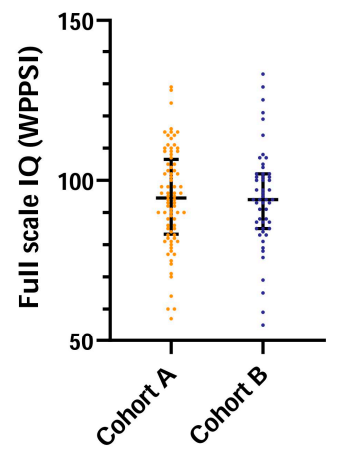

(B)

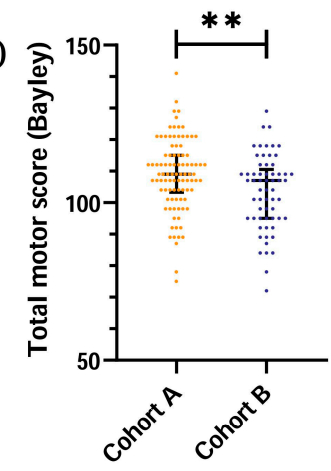

(D)

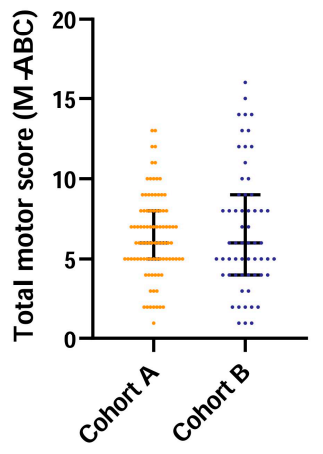

Figure 3. Cognitive $(\mathbf{A}, \mathbf{C})$ and motor $(\mathbf{B}, \mathbf{D})$ outcome at both follow-up ages for cohort $\mathrm{A}$ and $\mathrm{B}$. Each data point represents a score of an individual infant. Lines represent the median with interquartile range. ${ }^{* *} p<0.01$. Bayley: Bayley Scales of Infant and Toddler-Development, assessed at 2 years corrected age. WPPSI: Wechsler Preschool and Primary Scale of Intelligence, assessed at 5.9 years chronological age. M-ABC: Movement Assessment Battery for Children, assessed at 5.9 years chronological age. 
Table 4. Multivariable regression model of the nutritional cohort and other clinical variables in relation to cognitive and motor outcomes at both follow-up ages.

\begin{tabular}{|c|c|c|c|c|}
\hline & Cognition 2 Years CA & $\begin{array}{c}\text { Motor } 2 \text { Years } \\
\text { CA }\end{array}$ & $\begin{array}{c}\text { Cognition } 5.9 \text { Years } \\
\text { ChA }\end{array}$ & Motor 5.9 Years ChA \\
\hline Nutritional cohort $($ ref $=$ cohort A) & $2.6(-2.3$ to 7.4$)$ & $-5.2(-8.9$ to -1.5$) * *$ & $0.2(-5.5$ to 5.5$)$ & $0.4(-0.6$ to 1.5$)$ \\
\hline Gestational age (days) & $0.1(-0.2$ to 0.5$)$ & $0.2(-0.1$ to 0.5$)$ & $-0.1(-0.5$ to 0.3$)$ & $0.0(-0.1$ to 0.1$)$ \\
\hline Gender (ref = male) & $2.6(-2.2$ to 7.3$)$ & $1.1(-2.6$ to 4.7$)$ & $1.7(-3.5$ to 6.9$)$ & $1.5(0.5$ to 2.5$) * *$ \\
\hline Birth weight Z-score & $2.0(-0.7$ to 4.7$)$ & $2.8(0.8$ to 4.9$) * *$ & $-0.9(-3.9$ to 2.1$)$ & $0.1(-0.5$ to 0.7$)$ \\
\hline Severe illness $($ ref $=$ no) & $1.4(-3.7$ to 6.5$)$ & $-2.4(-6.3$ to 1.4$)$ & $0.0(-5.6$ to 5.6$)$ & $-1.3(-2.4$ to -0.2$) *$ \\
\hline \multicolumn{5}{|l|}{ Maternal education (ref = low) } \\
\hline middle & $3.3(-3.2$ to 9.7$)$ & $1.0(-3.8$ to 5.9$)$ & 10 (2.6 to 17.5$) * *$ & $0.2(-0.6$ to 2.3$)$ \\
\hline high & $11.9(5.1 \text { to } 18.6)^{* *}$ & $2.9(-2.1$ to 8.0$)$ & $13.4(5.8$ to 21.1$) * *$ & $0.8(-0.6$ to 2.3$)$ \\
\hline Severe brain injury $($ ref = no) & $-0.7(-8.3$ to 6.9$)$ & $-2.3(-8.2$ to 3.5$)$ & $9.1(0.3$ to 17.9$) *$ & $-0.4(-2.1$ to 1.3$)$ \\
\hline
\end{tabular}

Numbers presented are beta-coefficients with $95 \%$ confidence interval. $\mathrm{CA}=$ corrected age; ChA $=$ chronological age; Ref $=$ reference. ${ }^{*} p<0.05 ;{ }^{* *} p<0.01$.

After adjusting for confounders, total protein intake was negatively associated with total motor scores at 2 years $\mathrm{CA}(\mathrm{B}=-6.7,95 \% \mathrm{CI}-10.8$ to $-2.7, p=0.001)$. Enteral and parenteral protein intake, and total, enteral, and parenteral lipid and caloric intake were not significantly associated with outcome (Tables 5-7; data on enteral and parenteral intake not shown).

Table 5. Multivariable regression model of daily protein intake and other clinical variables in relation to cognitive and motor outcomes at both follow-up ages.

\begin{tabular}{|c|c|c|c|c|}
\hline & Cognition 2 Years CA & $\begin{array}{c}\text { Motor } 2 \text { Years } \\
\text { CA }\end{array}$ & $\begin{array}{c}\text { Cognition } 5.9 \text { Years } \\
\text { ChA }\end{array}$ & Motor 5.9 Years ChA \\
\hline Daily protein intake (grams / kg) & $-2.7(-8.1$ to 2.7$)$ & $-6.7(-10.8$ to -2.7$) * *$ & $-1.0(-6.9$ to 4.9$)$ & $-0.6(-1.8$ to 0.5$)$ \\
\hline Gestational age (days) & $0.1(-0.2$ to 0.5$)$ & $0.2(-0.1$ to 0.4$)$ & $-0.1(-0.5$ to 0.3$)$ & $0.0(-0.1$ to 0.1$)$ \\
\hline Gender $($ ref $=$ male $)$ & $2.3(-2.5$ to 7.0$)$ & $1.0(-2.6$ to 4.6$)$ & $1.6(-3.6$ to 6.8$)$ & $1.4(0.4 \text { to } 2.4)^{* *}$ \\
\hline Birth weight Z-score & $1.9(-0.8$ to 4.6$)$ & $2.7(0.7$ to 4.7$) *$ & $-0.9(-3.9$ to 2.1$)$ & $0.1(-0.5$ to 0.6$)$ \\
\hline Severe illness $($ ref $=$ no) & $1.3(-3.8$ to 6.5$)$ & $-3.1(-6.9$ to 0.8$)$ & $-0.2(-5.9$ to 5.5$)$ & $-1.3(-2.4$ to -0.2$)$ * \\
\hline \multicolumn{5}{|l|}{ Maternal education $($ ref $=$ low $)$} \\
\hline middle & $3.8(-2.7$ to 10.3$)$ & $1.8(-3.0$ to 6.6$)$ & $10.3(2.7$ to 17.9$) * *$ & $0.4(-1.0$ to 1.8$)$ \\
\hline high & $12.9(6.2 \text { to } 19.6)^{\#}$ & $2.9(-2.1$ to 7.8$)$ & $13.7(6.0$ to 21.4$) * *$ & $1.1(-0.4$ to 2.5$)$ \\
\hline Severe brain injury $($ ref = no) & $-0.8(-8.4$ to 6.9$)$ & $-2.5(-8.3$ to 3.2$)$ & $9.0(0.2$ to 17.8$) *$ & $-0.5(-2.2$ to 1.3$)$ \\
\hline
\end{tabular}

Numbers presented are beta-coefficients with $95 \%$ confidence interval. $\mathrm{CA}=$ corrected age; $\mathrm{ChA}=$ chronological age; Ref $=$ reference. ${ }^{*} p<0.05 ;{ }^{* *} p<0.01,{ }^{\#} p<0.001$.

Table 6. Multivariable regression model of daily lipid intake and other clinical variables in relation to cognitive and motor outcomes at both follow-up ages.

\begin{tabular}{|c|c|c|c|c|}
\hline & Cognition 2 Years CA & $\begin{array}{c}\text { Motor } 2 \text { Years } \\
\text { CA }\end{array}$ & $\begin{array}{c}\text { Cognition } 5.9 \text { Years } \\
\text { ChA }\end{array}$ & Motor 5.9 Years ChA \\
\hline Daily lipid intake (grams/kg) & $0.2(-3.4$ to 3.9$)$ & $0.1(-2.7$ to 2.9$)$ & $-0.8(-4.7$ to 3.2$)$ & $0.0(-0.7$ to 0.8$)$ \\
\hline Gestational age (days) & $0.1(-0.2$ to 0.5$)$ & $0.2(-0.1$ to 0.5$)$ & $-0.1(-0.5$ to 0.3$)$ & $0.0(-0.1$ to 0.1$)$ \\
\hline Gender (ref = male) & $2.5(-2.4$ to 7.3$)$ & $1.3(-2.4$ to 5.1$)$ & $1.6(-3.6$ to 6.8$)$ & $1.5(0.5$ to 2.5$) * *$ \\
\hline Birth weight Z-score & $2.0(-0.7$ to 4.7$)$ & $2.9(0.8 \text { to } 5.0)^{* *}$ & $-0.9(-3.9$ to 2.1$)$ & $0.1(-0.5$ to 0.6$)$ \\
\hline Severe illness $($ ref $=$ no) & $1.7(-4.1$ to 7.5$)$ & $-2.4(-6.9$ to 2.1$)$ & $-0.5(-6.8$ to 5.7$)$ & $-1.3(-2.5$ to -0.1$)$ * \\
\hline \multicolumn{5}{|l|}{ Maternal education $($ ref $=$ low $)$} \\
\hline middle & $3.4(-3.1$ to 9.9$)$ & $0.9(-4.1$ to 5.9$)$ & $10.1(2.7$ to 17.6$) * *$ & $0.3(-1.1$ to 1.6$)$ \\
\hline high & $12.4(5.8 \text { to } 19.1)^{\#}$ & $1.7(-3.4$ to 6.8$)$ & $13.5(5.9$ to 21.0$) * *$ & $0.9(-0.5$ to 2.4$)$ \\
\hline Severe brain injury $($ ref $=$ no $)$ & $-0.8(-8.4$ to 6.9$)$ & $-2.5(-8.5$ to 3.5$)$ & $9.3(0.4$ to 18.1$) *$ & $-0.4(-2.1$ to 1.3$)$ \\
\hline
\end{tabular}

Numbers presented are beta-coefficients with $95 \%$ confidence interval. $\mathrm{CA}=$ corrected age; $\mathrm{ChA}=$ chronological age; Ref $=$ reference. ${ }^{*} p<0.05 ;{ }^{* *} p<0.01,{ }^{\#} p<0.001$. 
Table 7. Multivariable regression model of daily caloric intake and other clinical variables in relation to cognitive and motor outcomes at both follow-up ages.

\begin{tabular}{lcccc}
\hline & Cognition 2 Years CA & Motor 2 Years CA & $\begin{array}{c}\text { Cognition 5.9 Years } \\
\text { ChA }\end{array}$ & Motor 5.9 Years ChA \\
\hline Daily caloric intake (kCal/kg) & $0.0(-0.3$ to 0.3$)$ & $-0.1(-0.2$ to 0.1$)$ & $-0.1(-0.3$ to 0.2$)$ & $0.0(-0.1$ to 0.1$)$ \\
Gestational age (days) & $0.1(-0.2$ to 0.5$)$ & $0.2(-0.1$ to 0.5$)$ & $-0.1(-0.5$ to 0.3$)$ & $0.0(-0.1$ to 0.1$)$ \\
Gender (ref = male) & $2.4(-2.4$ to 7.2$)$ & $1.3(-2.5$ to 5.0$)$ & $1.6(-3.6$ to 6.8$)$ & $1.5(0.5$ to 2.5$) * *$ \\
Birth weight Z-score & $2.0(-0.7$ to 4.7$)$ & $2.9(0.8$ to 5.0$) * *$ & $-0.9(-3.9$ to 2.1$)$ & $0.1(-0.5$ to 0.7$)$ \\
Severe illness (ref = no) & $1.5(-4.2$ to 7.3$)$ & $-3.0(-7.5$ to 1.4$)$ & $-0.8(-7.0$ to 5.4$)$ & $-1.2(-2.5$ to -0.0$) *$ \\
Maternal education (ref = low) & & & & \\
$\quad$ middle & $3.4(-3.1$ to 9.9$)$ & $1.0(-4.0$ to 5.9$)$ & $10.2(2.7 \text { to } 17.6)^{* *}$ & $0.3(-0.5$ to 2.4$)$ \\
$\quad$ high & $12.4(5.8$ to 19.1$)$ & $1.7(-3.4$ to 6.8$)$ & $13.6(6.0 \text { to } 21.1)^{* *}$ & $0.9(-0.5$ to 2.4$)$ \\
Severe brain injury (ref = no) & $-0.7(-8.4$ to 7.0$)$ & $-2.4(-8.4$ to 3.6$)$ & $9.2(0.4 \text { to } 18.0)^{*}$ & $-0.4(-2.2$ to 1.3$)$ \\
\hline
\end{tabular}

Numbers presented are beta-coefficients with $95 \%$ confidence interval. $\mathrm{CA}=$ corrected age; $\mathrm{ChA}=$ chronological age; Ref $=$ reference. ${ }^{*} p<0.05 ;{ }^{* *} p<0.01$.

\section{Discussion}

This study showed that EP infants who received the new nutritional regimen, containing more rapidly increased, higher protein intake in the first 28 postnatal days, had increased FA values in several white matter tracts at TEA but lower motor scores at 2 years $\mathrm{CA}$, compared to EP infants receiving the old nutritional regimen. In addition, total and enteral protein intakes during the first 28 postnatal days were positively associated with FA at TEA in similar tracts, and total protein intake was negatively associated with motor scores at 2 years CA. Nutritional intake was not associated with NDO at 5.9 years chronological age.

\subsection{Protein Intake and White Matter Integrity}

In our study, total and enteral protein intakes during the first 28 postnatal days were positively associated with white matter integrity measured by DTI at TEA. Similar findings have previously been reported for enteral protein intake [3,8]. Enteral and total protein intakes in preterm infants have also been linked to other markers of brain development, such as linear brain measurements [29] and long-term brain connectivity [30], respectively.

Dietary protein intake is essential for brain growth and myelination during early preterm life [15,31], especially for preterm infants, as they cannot yet synthesize all nonessential amino acids endogenously $[15,32,33]$. Interestingly, preterm breast milk contains higher amounts of protein during the first postnatal days compared to term breast milk [34], indicating the importance of protein intake for preterm development. Protein may affect brain development through different pathways. Protein is used as building blocks in all tissues, including the brain [35,36]. In fact, $25 \%$ of myelin consists of protein [37]. Additionally, protein intake in preterm infants is positively associated with levels of insulin-like growth factor 1 (IGF-1) [38-40]. IGF-1 stimulates protein synthesis, glucose uptake, and cell development [33]. IGF-1 is important for brain growth in very preterm infants [41] and white matter organization in very low birth weight infants [42].

Although our findings highlight a predominant effect of total protein intake, a slightly stronger effect of enteral versus parenteral protein intake on FA was also found. In contrast to parenteral protein intake, enteral protein intake influences the gastrointestinal tract. This may reduce inflammation by elevation of IGF- 1 levels $[40,43,44]$ and by communication with the microbiome-gut-brain axis, contributing to white matter development $[15,45]$. However, the effect of parenteral protein intake on brain development may be confounded by illness, since the sickest infants receive parenteral nutrition for the longest time and are most vulnerable to brain injury.

\subsection{Protein Intake and Neurodevelopmental Outcome}

The negative association between total protein intake and motor development was an unexpected but not completely new finding. In preterm infants, early parenteral 
protein intake has been associated with lower M-ABC scores [46], higher odds on cerebral palsy [46], and lower cognitive scores [47]. Additionally, increased early total protein intake was associated with higher odds on neurodevelopmental impairments [14]. On the contrary, several studies show positive associations between total protein intake $[3,12]$ or enteral protein intake $[46,48,49]$ and NDO [15]. Two recent Cochrane reviews that assessed higher versus lower protein intake in formula-fed low birth weight infants $(<2500 \mathrm{~g})$ [50] and in parenteral nutrition in very preterm or low birth weight infants [51] could not evaluate the effect of protein intake on NDO, due to a lack of studies evaluating NDO. Conflicting and inconclusive results, together with our results, highlight the complex relationship between (the route of) protein intake and brain development.

Besides increased protein intake, infants in cohort B also had an increased protein/energy ratio compared to infants in cohort A. An adequate amount of non-protein energy is needed for protein synthesis, and to prevent unwanted oxidation of amino acids to ammonia and urea [52]. In high concentrations, ammonia and urea can be toxic [52]. Additionally, infants in cohort B received relatively more protein and lipids parenterally compared to cohort A. The aim of the new nutritional regimen was to increase protein and lipids but not to shorten the days of parenteral nutrition. Since protein and lipids are mostly provided through parenteral nutrition in the first postnatal days, and time to full enteral feeding did not change, the new nutritional regimen led to relatively more parenteral protein and lipid intake in cohort B. This may have contributed to lower motor scores in cohort B, as parenteral protein intake has previously been associated with impaired brain development and/or NDO $[29,46,47]$.

\subsection{Clinical Relevance}

Protein intake might provide an opportunity to improve long-term outcomes through improved white matter integrity, although that could not be shown in our cohort. Global white matter development is considered a prerequisite for cognitive development [53], and FA at TEA in preterm born infants has previously been associated with improved NDO at 2 years CA [54,55].

Infants in cohort $B$ had lower motor scores at 2 years $C A$ compared to infants in cohort $\mathrm{A}$, but the clinical relevance of this finding remains unclear. The mean cognitive and motor outcomes at 2 years CA in our cohort were well above the normative mean, even in cohort B. In addition, the differences in motor score at 2 years CA were not sustained to 5.9 years chronological age. Therefore, it seems best to conclude that providing more protein during the early postnatal period, in relatively healthy EP born infants, has no additional effect on NDO. Increased protein intake did not decrease motor scores below the normal range.

Studies that assess the effects of nutrition on long-term NDO are often underpowered, which makes it difficult to draw final conclusions. The conflicting evidence from previous studies regarding protein intake and neurodevelopment, together with our results, highlight the need for adequately powered short- and long-term follow-up studies after nutritional interventions.

\subsection{Limitations}

Our study has several limitations. First, the new nutritional regimen aimed to provide more protein and lipids, but lipid intake between cohort A and B was similar. Therefore, only protein intake differed between cohort A and B. Second, our cohort consisted of relatively healthy infants, as confirmed by the mean cognitive and motor scores within the normal range. Therefore, a potential positive effect of nutritional intake on outcome may have been more difficult to detect. Third, we have no information on breast milk or formula intake. We are aware that breast milk plays an important role in brain development $[56,57]$. Although we do not expect a difference in breast milk intake between cohort A and B, as there was no change in protocols regarding the use of breast milk, this cannot be completely ruled out. Fourth, the DTI sequence was changed during the study period, which might have influenced FA values. To limit the effect of the DTI sequence on our analyses, a scan 
protocol was included as a confounding factor in the analyses. Fifth, in 2016, there was a change in staff performing the outcome assessment. Therefore, most children in cohort $B$ were evaluated by other clinical staff than children in cohort A. Although the new staff were equally qualified, and no differences were seen in cognitive outcome, it cannot be ruled out that this change may have contributed to the difference in motor outcome at 2 years CA. Sixth, severe brain injury was positively associated with cognitive outcome at 5.9 years chronological age. This unexpected association was likely due to the small number of infants with severe brain injury, combined with unevenly distributed levels of maternal education. By chance, all but three infants with severe brain injury had mothers with middle or high education. Seventh, our study results may have been influenced by small changes in healthcare over time due to the retrospective design of our study. However, besides a change in nutrition protocol, there were no major changes in clinical protocols. Finally, after hospital discharge, many factors may influence neurodevelopment. We only corrected our analyses for confounders from birth until TEA, and may have missed other contributing factors.

\section{Conclusions}

In our cohort of EP infants, protein intake, but not lipid or caloric intake, in the first 28 postnatal days was associated with increased FA in several white matter tracts, and lower motor scores at 2 years CA, although still within the normal range. The interplay between nutritional intake and later neurodevelopment is complex. Simply providing more protein does not necessarily contribute to improved neurodevelopment.

Supplementary Materials: The following are available online at https:/ /www.mdpi.com/article/ 10.3390/nu13103409/s1, Table S1: Baseline characteristics of the included and excluded children, Table S2: Baseline characteristics of the children included in cohort A and B, Figure S1: Enteral protein intake and FA.

Author Contributions: Conceptualization, N.H.P.C., J.D., R.M.v.E., M.J.N.L.B., M.L.T. and N.E.v.d.A.; Data curation, L.M.H., E.J. and P.E.v.B.; Formal analysis, L.M.H., E.J., P.E.v.B., F.G. and N.E.v.d.A.; Investigation, L.M.H., E.J., P.E.v.B., H.F.N.S.d.V., M.J.C.E. and C.K.-E.; Methodology, N.H.P.C., J.D., R.M.v.E., M.J.N.L.B., M.L.T. and N.E.v.d.A.; Supervision, J.D., R.M.v.E., M.J.N.L.B., M.L.T. and N.E.v.d.A.; Visualization, L.M.H. and E.J.; Writing—original draft, L.M.H., E.J. and P.E.v.B.; Writing—review and editing, L.M.H., E.J., P.E.v.B., F.G., N.H.P.C., H.F.N.S.d.V., M.J.C.E., C.K.-E., J.D., R.M.v.E., M.J.N.L.B., M.L.T. and N.E.v.d.A., L.M.H. and E.J. contributed equally to this paper; M.L.T. and N.E.v.d.A. contributed equally to this paper. All authors have read and agreed to the published version of the manuscript.

Funding: L.M.H. received funding from the Athena grant, 'Utrecht Center for Food and Healthresearch program specialized nutrition', subsidy from the Dutch Ministry of Economic Affairs, Utrecht Province and the municipality of Utrecht.

Institutional Review Board Statement: Ethical review and approval were waived for this study, because all data were obtained as part of standard clinical care.

Informed Consent Statement: Patient consent was waived, because all data were obtained as part of standard clinical care. Written informed consent was not required according to the medical ethical review board of the University Medical Center Utrecht, The Netherlands.

Data Availability Statement: The data presented in this study are available on request from the corresponding author. The data are not publicly available due to privacy restrictions and the General Data Protection Regulation does not allow sharing pseudonymized data without informed consent.

Conflicts of Interest: The authors declare no conflict of interest. 


\section{References}

1. Vinall, J.; Grunau, R.E.; Brant, R.; Chau, V.; Poskitt, K.J.; Synnes, A.R.; Miller, S.P. Slower postnatal growth is associated with delayed cerebral cortical maturation in preterm newborns. Sci. Transl. Med. 2013, 5, 168ra8. [CrossRef] [PubMed]

2. Bell, K.A.; Matthews, L.G.; Cherkerzian, S.; Palmer, C.; Drouin, K.; Pepin, H.L.; Ellard, D.; Inder, T.E.; Ramel, S.E.; Belfort, M.B Associations of Growth and Body Composition with Brain Size in Preterm Infants. J. Pediatr. 2019, 214, 20-26.e2. [CrossRef] [PubMed]

3. Coviello, C.; Keunen, K.; Kersbergen, K.J.; Groenendaal, F.; Leemans, A.; Peels, B.; Isgum, I.; Viergever, M.A.; de Vries, L.S.; Buonocore, G.; et al. Effects of early nutrition and growth on brain volumes, white matter microstructure, and neurodevelopmental outcome in preterm newborns. Pediatr. Res. 2018, 83, 102-110. [CrossRef] [PubMed]

4. Belfort, M.B.; Rifas-Shiman, S.L.; Sullivan, T.; Collins, C.T.; McPhee, A.J.; Ryan, P.; Kleinman, K.P.; Gillman, M.W.; Gibson, R.A.; Makrides, M. Infant growth before and after term: Effects on neurodevelopment in preterm infants. Pediatrics 2011, 128, e899-e906. [CrossRef]

5. Frondas-Chauty, A.; Simon, L.; Branger, B.; Gascoin, G.; Flamant, C.; Ancel, P.Y.; Darmaun, D.; Roze, J.C. Early growth and neurodevelopmental outcome in very preterm infants: Impact of gender. Arch. Dis. Child. Fetal Neonatal Ed. 2014, 99, F366-F372. [CrossRef] [PubMed]

6. Guellec, I.; Lapillonne, A.; Marret, S.; Picaud, J.C.; Mitanchez, D.; Charkaluk, M.L.; Fresson, J.; Arnaud, C.; Flamant, C.; Cambonie, G.; et al. Effect of Intra- and Extrauterine Growth on Long-Term Neurologic Outcomes of Very Preterm Infants. J. Pediatr. 2016, 175, 93-99.e1. [CrossRef]

7. Ottolini, K.M.; Andescavage, N.; Keller, S.; Limperopoulos, C. Nutrition and the developing brain: The road to optimizing early neurodevelopment: A systematic review. Pediatr. Res. 2020, 87, 194-201. [CrossRef]

8. Schneider, J.; Fischer Fumeaux, C.J.; Duerden, E.G.; Guo, T.; Foong, J.; Graz, M.B.; Hagmann, P.; Chakravarty, M.M.; Huppi, P.S.; Beauport, L.; et al. Nutrient Intake in the First Two Weeks of Life and Brain Growth in Preterm Neonates. Pediatrics 2018, 141, e20172169. [CrossRef]

9. Beauport, L.; Schneider, J.; Faouzi, M.; Hagmann, P.; Huppi, P.S.; Tolsa, J.F.; Truttmann, A.C.; Fischer Fumeaux, C.J. Impact of Early Nutritional Intake on Preterm Brain: A Magnetic Resonance Imaging Study. J. Pediatr. 2017, 181, 29-36.e1. [CrossRef]

10. van Beek, P.E.; Claessens, N.H.P.; Makropoulos, A.; Groenendaal, F.; de Vries, L.S.; Counsell, S.J.; Benders, M. Increase in Brain Volumes after Implementation of a Nutrition Regimen in Infants Born Extremely Preterm. J. Pediatr. 2020, 223, 57-63.e5. [CrossRef]

11. Shim, S.Y.; Ahn, H.M.; Cho, S.J.; Park, E.A. Early aggressive nutrition enhances language development in very low-birthweight infants. Pediatr. Int. 2014, 56, 845-850. [CrossRef] [PubMed]

12. Stephens, B.E.; Walden, R.V.; Gargus, R.A.; Tucker, R.; McKinley, L.; Mance, M.; Nye, J.; Vohr, B.R. First-week protein and energy intakes are associated with 18-month developmental outcomes in extremely low birth weight infants. Pediatrics 2009, 123, 1337-1343. [CrossRef] [PubMed]

13. Cester, E.A.; Bloomfield, F.H.; Taylor, J.; Smith, S.; Cormack, B.E. Do recommended protein intakes improve neurodevelopment in extremely preterm babies? Arch. Dis. Child. Fetal Neonatal Ed. 2015, 100, F243-F247. [CrossRef]

14. Barreault, S.; Bellanger, A.; Berneau, P.; de La Pintiere, A.; Lallemant, C.; Beuchee, A. Impact of early protein and energy intakes on neurodevelopment at 2 years of corrected age in very low birth weight infants: A single-center observational study. PLoS ONE 2019, 14, e0218887. [CrossRef] [PubMed]

15. Cormack, B.E.; Harding, J.E.; Miller, S.P.; Bloomfield, F.H. The Influence of Early Nutrition on Brain Growth and Neurodevelopment in Extremely Preterm Babies: A Narrative Review. Nutrients 2019, 11, 2029. [CrossRef] [PubMed]

16. Chan, S.H.; Johnson, M.J.; Leaf, A.A.; Vollmer, B. Nutrition and neurodevelopmental outcomes in preterm infants: A systematic review. Acta Paediatr. 2016, 105, 587-599. [CrossRef] [PubMed]

17. Hortensius, L.M.; van Elburg, R.M.; Nijboer, C.H.; Benders, M.; de Theije, C.G.M. Postnatal Nutrition to Improve Brain Development in the Preterm Infant: A Systematic Review From Bench to Bedside. Front. Physiol. 2019, 10, 961. [CrossRef]

18. Dutch Perinatal Registry. Available online: www.perined.nl (accessed on 21 August 2018).

19. Statistics Netherlands. Education Level. Available online: https://www.cbs.nl/en-gb/news/2018/20/well-being-notdistributed-equally/education-level (accessed on 6 June 2018).

20. Lafeber, H.N.; van Zoeren-Grobben, D.; van Beek, R.H.T.; Christmann, V. Werkboek Enterale en Parenterale Voeding bij Pasgeborenen; VU University Press: Amsterdam, The Netherlands, 2012.

21. Smith, S.M.; Jenkinson, M.; Woolrich, M.W.; Beckmann, C.F.; Behrens, T.E.; Johansen-Berg, H.; Bannister, P.R.; De Luca, M.; Drobnjak, I.; Flitney, D.E.; et al. Advances in functional and structural MR image analysis and implementation as FSL. Neuroimage 2004, 23 (Suppl. 1), S208-S219. [CrossRef]

22. Smith, S.M.; Jenkinson, M.; Johansen-Berg, H.; Rueckert, D.; Nichols, T.E.; Mackay, C.E.; Watkins, K.E.; Ciccarelli, O.; Cader, M.Z.; Matthews, P.M.; et al. Tract-based spatial statistics: Voxelwise analysis of multi-subject diffusion data. Neuroimage 2006, 31, 1487-1505. [CrossRef]

23. Andersson, J.L.R.; Jenkinson, M.; Smith, S. Non-linear optimisation. FMRIB technical report TR07JA. Practice 2007. Available online: www.fmrib.ox.ac.uk/analysis/techrep (accessed on 7 February 2021). 
24. Andersson, J.L.R.; Jenkinson, M.; Smith, S. Non-linear registration, aka Spatial normalisation FMRIB technical report TR07JA2. FMRIB Anal. Group Univ. Oxf. 2007, 2, e21. Available online: www.fmrib.ox.ac.uk/analysis/techrep (accessed on 7 February 2021).

25. Winkler, A.M.; Ridgway, G.R.; Webster, M.A.; Smith, S.M.; Nichols, T.E. Permutation inference for the general linear model. Neuroimage 2014, 92, 381-397. [CrossRef]

26. Smith, S.M.; Nichols, T.E. Threshold-free cluster enhancement: Addressing problems of smoothing, threshold dependence and localisation in cluster inference. Neuroimage 2009, 44, 83-98. [CrossRef]

27. Nichols, T.E.; Holmes, A.P. Nonparametric permutation tests for functional neuroimaging: A primer with examples. Hum. Brain Mapp. 2002, 15, 1-25. [CrossRef] [PubMed]

28. R Core Team. R: A Language and Environment for Statistical Computing; R Foundation for Statistical Computing: Vienna, Austria, 2020. Available online: https:/ / www.R-project.org (accessed on 6 July 2021).

29. Terrin, G.; De Nardo, M.C.; Boscarino, G.; Di Chiara, M.; Cellitti, R.; Ciccarelli, S.; Gasparini, C.; Parisi, P.; Urna, M.; Ronchi, B.; et al. Early Protein Intake Influences Neonatal Brain Measurements in Preterms: An Observational Study. Front. Neurol. 2020, 11, 885. [CrossRef] [PubMed]

30. Duerden, E.G.; Thompson, B.; Poppe, T.; Alsweiler, J.; Gamble, G.; Jiang, Y.; Leung, M.; Tottman, A.C.; Wouldes, T.; Miller, S.P.; et al. Early protein intake predicts functional connectivity and neurocognition in preterm born children. Sci. Rep. 2021, 11, 4085 . [CrossRef] [PubMed]

31. Georgieff, M.K. Nutrition and the developing brain: Nutrient priorities and measurement. Am. J. Clin. Nutr. 2007, 85, 614S-620S. [CrossRef] [PubMed]

32. Morgan, C.; Burgess, L. High Protein Intake Does Not Prevent Low Plasma Levels of Conditionally Essential Amino Acids in Very Preterm Infants Receiving Parenteral Nutrition. JPEN J. Parenter. Enteral Nutr. 2017, 41, 455-462. [CrossRef]

33. Yumani, D.F.; Lafeber, H.N.; van Weissenbruch, M.M. Dietary proteins and IGF I levels in preterm infants: Determinants of growth, body composition, and neurodevelopment. Pediatr. Res. 2015, 77, 156-163. [CrossRef]

34. Gidrewicz, D.A.; Fenton, T.R. A systematic review and meta-analysis of the nutrient content of preterm and term breast milk. BMC Pediatr. 2014, 14, 216. [CrossRef]

35. Hay, W.W., Jr. Nutritional Support Strategies for the Preterm Infant in the Neonatal Intensive Care Unit. Pediatr. Gastroenterol. Hepatol. Nutr. 2018, 21, 234-247. [CrossRef]

36. Hay, W.W.; Thureen, P. Protein for preterm infants: How much is needed? How much is enough? How much is too much? Pediatr. Neonatol. 2010, 51, 198-207. [CrossRef]

37. Jahn, O.; Tenzer, S.; Werner, H.B. Myelin proteomics: Molecular anatomy of an insulating sheath. Mol. Neurobiol. 2009, 40, 55-72. [CrossRef] [PubMed]

38. Socha, P.; Grote, V.; Gruszfeld, D.; Janas, R.; Demmelmair, H.; Closa-Monasterolo, R.; Subias, J.E.; Scaglioni, S.; Verduci, E.; Dain, E.; et al. Milk protein intake, the metabolic-endocrine response, and growth in infancy: Data from a randomized clinical trial. Am. J. Clin. Nutr. 2011, 94, 1776S-1784S. [CrossRef] [PubMed]

39. Engstrom, E.; Niklasson, A.; Wikland, K.A.; Ewald, U.; Hellstrom, A. The role of maternal factors, postnatal nutrition, weight gain, and gender in regulation of serum IGF-I among preterm infants. Pediatr. Res. 2005, 57, 605-610. [CrossRef] [PubMed]

40. Yumani, D.F.J.; Calor, A.K.; van Weissenbruch, M.M. The Course Of IGF-1 Levels and Nutrient Intake in Extremely and Very Preterm Infants During Hospitalisation. Nutrients 2020, 12, 675. [CrossRef] [PubMed]

41. Hansen-Pupp, I.; Hovel, H.; Hellstrom, A.; Hellstrom-Westas, L.; Lofqvist, C.; Larsson, E.M.; Lazeyras, F.; Fellman, V.; Huppi, P.S.; Ley, D. Postnatal decrease in circulating insulin-like growth factor-I and low brain volumes in very preterm infants. J. Clin. Endocrinol. Metab. 2011, 96, 1129-1135. [CrossRef]

42. Okuma, C.; Hernandez, M.I.; Rodriguez, P.; Flores, R.; Avila, A.; Cavada, G.; Kopplin, E.; Rossel, K.; Iniguez, G.; Mericq, $\mathrm{V}$. Microstructural brain and multivoxel spectroscopy in very low birth weight infants related to insulin-like growth factor concentration and early growth. Horm. Res. Paediatr. 2013, 79, 197-207. [CrossRef]

43. Wojnar, M.M.; Fan, J.; Li, Y.H.; Lang, C.H. Endotoxin-induced changes in IGF-I differ in rats provided enteral vs. parenteral nutrition. Am. J. Physiol. 1999, 276, E455-E464. [CrossRef]

44. O'Leary, M.J.; Xue, A.; Scarlett, C.J.; Sevette, A.; Kee, A.J.; Smith, R.C. Parenteral versus enteral nutrition: Effect on serum cytokines and the hepatic expression of mRNA of suppressor of cytokine signaling proteins, insulin-like growth factor-1 and the growth hormone receptor in rodent sepsis. Crit. Care 2007, 11, R79. [CrossRef]

45. Keunen, K.; van Elburg, R.M.; van Bel, F.; Benders, M.J. Impact of nutrition on brain development and its neuroprotective implications following preterm birth. Pediatr. Res. 2015, 77, 148-155. [CrossRef]

46. Tottman, A.C.; Alsweiler, J.M.; Bloomfield, F.H.; Gamble, G.D.; Jiang, Y.; Leung, M.; Poppe, T.; Thompson, B.; Wouldes, T.A.; Harding, J.E.; et al. Relationships Between Early Neonatal Nutrition and Neurodevelopment at School Age in Children Born Very Preterm. J. Pediatr. Gastroenterol. Nutr. 2020, 70, 72-78. [CrossRef]

47. Blanco, C.L.; Gong, A.K.; Schoolfield, J.; Green, B.K.; Daniels, W.; Liechty, E.A.; Ramamurthy, R. Impact of early and high amino acid supplementation on ELBW infants at 2 years. J. Pediatr. Gastroenterol. Nutr. 2012, 54, 601-607. [CrossRef]

48. Cormack, B.E.; Bloomfield, F.H.; Dezoete, A.; Kuschel, C.A. Does more protein in the first week of life change outcomes for very low birthweight babies? J. Paediatr. Child Health 2011, 47, 898-903. [CrossRef] [PubMed] 
49. Biasini, A.; Monti, F.; Laguardia, M.C.; Stella, M.; Marvulli, L.; Neri, E. High protein intake in human/maternal milk fortification for $\leq 1250$ gr infants: Intrahospital growth and neurodevelopmental outcome at two years. Acta Biomed. 2018, 88, 470-476. [CrossRef] [PubMed]

50. Fenton, T.R.; Al-Wassia, H.; Premji, S.S.; Sauve, R.S. Higher versus lower protein intake in formula-fed low birth weight infants. Cochrane Database Syst. Rev. 2020, 6, CD003959. [CrossRef]

51. Osborn, D.A.; Schindler, T.; Jones, L.J.; Sinn, J.K.; Bolisetty, S. Higher versus lower amino acid intake in parenteral nutrition for newborn infants. Cochrane Database Syst. Rev. 2018, 3, CD005949. [CrossRef] [PubMed]

52. Embleton, N.D.; van den Akker, C.H.P. Protein intakes to optimize outcomes for preterm infants. Semin. Perinatol. 2019, 43, 151154. [CrossRef]

53. Girault, J.B.; Cornea, E.; Goldman, B.D.; Knickmeyer, R.C.; Styner, M.; Gilmore, J.H. White matter microstructural development and cognitive ability in the first 2 years of life. Hum. Brain Mapp. 2019, 40, 1195-1210. [CrossRef]

54. van Kooij, B.J.; van Pul, C.; Benders, M.J.; van Haastert, I.C.; de Vries, L.S.; Groenendaal, F. Fiber tracking at term displays gender differences regarding cognitive and motor outcome at 2 years of age in preterm infants. Pediatr. Res. 2011, 70, 626-632. [CrossRef]

55. van Kooij, B.J.; de Vries, L.S.; Ball, G.; van Haastert, I.C.; Benders, M.J.; Groenendaal, F.; Counsell, S.J. Neonatal tract-based spatial statistics findings and outcome in preterm infants. AJNR Am. J. Neuroradiol. 2012, 33, 188-194. [CrossRef]

56. Blesa, M.S.G.; Anblagan, D.; Telford, E.J.; Quigley, A.J.; Sparrow, S.; Serag, A.; Semple, S.I.; Blastin, M.; Boardman, J.P. Early breast milk exposure modifies brain connectivity in preterm infants. Neuroimage 2019, 184, 431-439. [CrossRef] [PubMed]

57. Chetta, K.E.; Schulz, E.V.; Wagner, C.L. Outcomes improved with human milk intake in preterm and full-term infants. Semin. Perinatol. 2021, 45, 151384. [CrossRef] [PubMed] 